\title{
Exploring local knowledge and socio-economic factors for touristic attractiveness and sustainability
}

\author{
Caterina De Lucia ${ }^{1}$ (D) | Pasquale Pazienza ${ }^{1}$ (D) | Pasquale Balena ${ }^{2}$ (D) | Diana Caporale ${ }^{3}$
}

${ }^{1}$ Department of Economics, University of Foggia, Foggia, Italy

${ }^{2}$ Laboratory of Spatial and Territorial Cognition, Technical University of Bari, Bari, Italy

${ }^{3}$ Department of Environmental Science and Policy, University of Milan, Milan, Italy

\section{Correspondence}

Caterina De Lucia, Department of Economics, University of Foggia, Largo Papa Giovanni Paolo II, n. 1, 71121 Foggia, Italy.

Email: caterina.delucia@gmail.com; caterina. delucia@unifg.it

\begin{abstract}
The present study investigates residents' perception of tourism as a sustainable development driver and explores the reasons why residents recognize their own place of residence as an attractive tourism destination. The work considers one of Italy's most visited tourist destinations (Puglia) and uses quantitative (i.e., inferential and text mining) and qualitative (i.e., survey) approaches. Main results reveal that socio-economic and environmental factors positively affect residents' perception of tourism as a driver of sustainable development. Furthermore, the spatial dimensions of the territories of Puglia, perceived by indigenous local knowledge, are key elements for tourist attractiveness of its destinations.
\end{abstract}

\section{KEYWORDS}

local knowledge, ordered logistic regression, resident perception of tourism, sustainable development, text mining, touristic attractiveness

\section{1 | INTRODUCTION}

The role of tourism as a driver of sustainable development is fully recognized by the international scientific literature. The majority of studies focus on residents' perception of their own place because it is believed that they take for granted the potentialities of their local resources to contribute to local sustainable development and tourist attractiveness. While doing this, however, the international literature pays little attention to the issue of local knowledge.

For the purposes of the present work, local knowledge plays an important role.

It is strictly linked to resident perception because it is strongly rooted in the personal (and emotional) sphere of an individual and hence difficult to formalize, share, and/or transfer (Fazey, Fazey, Salisbury, Lindenmayer, \& Dovers, 2006; Nonaka, Konno, \& Toyama, 2001; Olaide \& Omolere, 2013). As a consequence, what residents know, feel, and express is key to the understanding of how socio-economic and environmental factors play a role in the residents' perception of tourism as a driver of local sustainable development.

This work focuses on the following research questions: (a) How socio-economic and environmental factors affect residents' perception of tourism as a driver of sustainable development? (b) Why do residents perceive their own place as an attractive tourism destination?

To answer to the above questions, in this study, we consider a pilot case $^{1}$ for the Puglia region in the south of Italy. We employ a stochastic model and a text mining (TM) analysis based on data retrieved from a survey.

Current literature, such as Haven-Tang and Jones (2012), emphasizes the role played by Monmouthshire in Wales (UK) as a place to promote rural tourism due to its historical, traditional, and cultural heritage. Recently, Pérez Gálvez, Granda, López-Guzmán, and Coronel (2017) draw attention to the links between gastronomy, heritage, and sustainable tourism of cities. The authors point out how a cultural destination, in addition to its heritage and gastronomy, is perceived as one of the best ways to promote tourism and intensify the sustainability of local economies. Similarly, Gugushvili, Salukvadze, and Salukvadze (2017) recognize the role of tourism "as engine of income and source of employment" (p. 49) in mountain regions of the former Soviet areas.

${ }^{1}$ The results of the pilot case are currently being further investigated for a bigger project under preparation for consideration at the regional authority. The bigger project aims to study the behaviour of a larger proportion of residents in the Puglia region. 
Another branch of studies addresses tourism under the lens of a knowledge system (Barnes, 2014; Tribe \& Liburd, 2016; Xin, Tribe, \& Chambers, 2013). These works illustrate the role of conceptual research and delineate how it can contribute to the formation of knowledge in tourism studies. This remark is also emphasized by the study of Barnes (2014), which highlights that knowledge requires an understanding about the creation of a tourism knowledge system and its consequences. Tribe and Liburd (2016) critically address and put together various epistemology and ontological visions that contribute to form a conceptual model for a tourism knowledge system. In particular, the authors recall the importance of indigenous knowledge defined as "knowledge originating from specific cultural, geographical and traditional circumstances" and that is "often embedded in oral traditions [...] passed on from generations through cosmologies, diaspora, storytelling, arts, crafts, spirituality, language and classification systems" (Tribe \& Liburd, 2016, p. 52).

Indigenous knowledge enables further understanding of tourism from the perspective of local people (the indigenous) and uncover new insights, needs, and perceptions, which are often ignored or neglected by the policymaker. In the context of local (indigenous) knowledge, the main literature concerns the attitudes of local residents towards tourism (Andereck, Valentine, Knopf, \& Vogt, 2005; Sharpley, 2014). Sharpley (2014), for example, reviews the majority of studies from 1984 to 2012 concerning various aspects of resident perception of tourism.

The measurement component of tourism that contributes to the sustainable development of a community is mainly present in the studies of Choi and Sirakaya (2006), Andereck, Valentine, Vogt, and Knopf (2007), and Andereck and Nyaupane (2011), which analyse tourism as driver of the quality of life. In particular, the work of Choi and Sirakaya (2006) develops a scale of six indicators to measure sustainable tourism developments. Their study, although weakly validated, is the first attempt to measure subjective expressions and perceptions in the field of sustainable tourism. Andereck et al. (2007) and Andereck and Nyaupane (2011) point out to two different studies on the quality of life and tourism. In the former paper, the authors analyse the case of existing differences between Hispanic and Anglo residents and support their research with the ethnicity theory. The latter study extends the former and includes a quantitative analysis based on inferential statistics and the development of a quality of life index for sustainable tourism.

Almeida-García, Balbuena-Vázquez, and Cortés Macías (2015) describe an in-depth review on resident perception of tourism impacts touching social, institutional, economic, and environmental aspects. Recently, Lundberg (2017) sheds light upon how different resident groups perceive various tourism impacts.

The present work is structured as follows: Section 2 describes the main literature background on the role of local knowledge in tourism studies; Section 3 presents the case study and the methodology; Section 4 illustrates and discusses the obtained results; Section 5 depicts main policy implications; and Section 6 concludes the work.

\section{2 | BACKGROUND}

\section{1 | The role of local (indigenous) knowledge}

Scholars have treated and compared different types of knowledge, although no borderline can be used to sort knowledge into clear-cut classes. The study by Raymond et al. (2010) covers several aspects that are relevant in the context of the present study. Figure 1 summarizes these aspects so that knowledge can be classified as (a) "local" and "generalized" knowledge that focuses on spatial aspects; (b) "formal" and "informal" knowledge highlighting legal/administrative aspects; (c) "novice/nonexpert" and "expert" knowledge that pays attention to the background or dimensional aspects of knowledge; and (d) "tacit," "implicit," and "explicit" knowledge that deals with the degree of knowledge expression.

Raymond et al. (2010) also argue about the existence of two subcategories of local knowledge: "personal experience" and "traditional cultural rules and norm." These can be interpreted as the main drivers of specific local knowledge (Figure 2).

This level of disaggregation that details local (indigenous) knowledge is often debated at the international level (Campolo, Bombino, \& Meduri, 2016; Hiwasaki, Luna, Syamsidik, \& Shaw, 2014; Raymond et al., 2010). For the purpose of the present work, the term local (indigenous) knowledge is used to include all forms of knowledge such as personal, which is based on (individual) experiential processes (Fazey et al., 2006; Polanyi \& Sen, 1966); lay, which reflects the most common interpretation given by individuals about a specific situation (Halfacree, 1995; Hansen, Holm, Frewer, Robinson, \& Sandøe, 2003); local or situated, which is based on understanding local phenomena (Kettle et al., 2014; Robertson \& McGee, 2003; Smith, 2001); tacit, which deals with an unconscious knowledge that is often latent, difficult to express (Fazey et al., 2006; Kumar, Morstatter, Zafarani, \& Liu, 2013; Smith, 2001); implicit, which is rooted in an individual but is not accessible to others (Fazey et al., 2006; Frappaolo, 2008); informal, which refers to knowledge acquired with different experiences, without structured rules and procedures (Bond, Viegas, Coelho, \& Selig, 2010; Pasquini \& Alexander, 2005; Van Herzele, 2004); nonexpert/ novice, which generally does not incorporate the depth of experience and expertise as expert knowledge does (Fazey et al., 2006; Nonaka et al., 2001); expert, which expresses the degree of experience of an

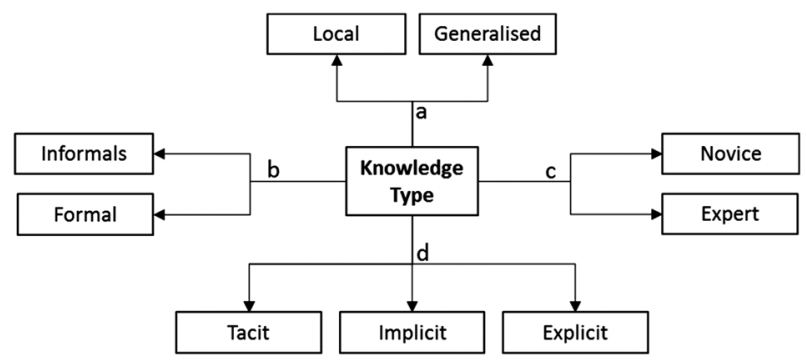

FIGURE 1 Dimensions of knowledge types derived from the environmental management literature. Adapted from Raymond et al. (2010) 




FIGURE 2 Types of knowledge from the field of environmental management literature (dashed and dotted lines relate to knowledge fields, but these are beyond the scope of the present work). Adapted from Raymond et al. (2010) [Colour figure can be viewed at wileyonlinelibrary.com]

(Van Camp, 2007). These forms of local knowledge, which can also be considered "marginal," could be decisive for understanding sociocultural dynamics and hence affect the tourist attractiveness of a place (Tickner, 2015).

\subsection{1 | Local (indigenous) knowledge in tourism studies}

Despite the current transformations of the society and economy at global level, a lot of information is embodied almost exclusively in local knowledge as the expression of local identity of a population. Generally, the places in which individuals live generate a high degree of local knowledge. People usually know interesting details of their surroundings such as historic, cultural, and commercial places. This information would be unknown to a tourist, unless a local person transferred his or her knowledge. This is actually what is meant by local knowledge in tourism studies: the knowledge and awareness that people who live in a particular place have about their territory (Smith, 2001).

The understanding of local knowledge has long been investigated, and pioneering works date back to the late 1970s (Pizam, 1978; Rothman, 1978). More recently, Pásková (2015) addresses the importance of local knowledge for Rio Coco Geopark in Nicaragua and the potentials for developing tourism attractiveness. 


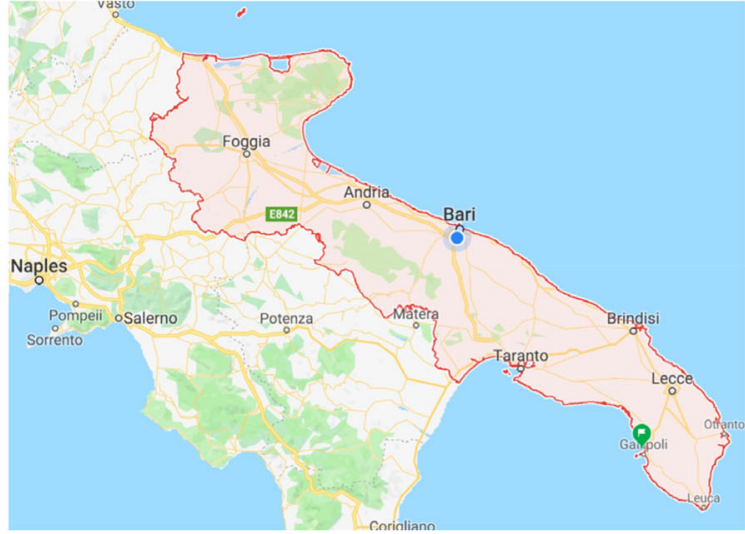

(a)

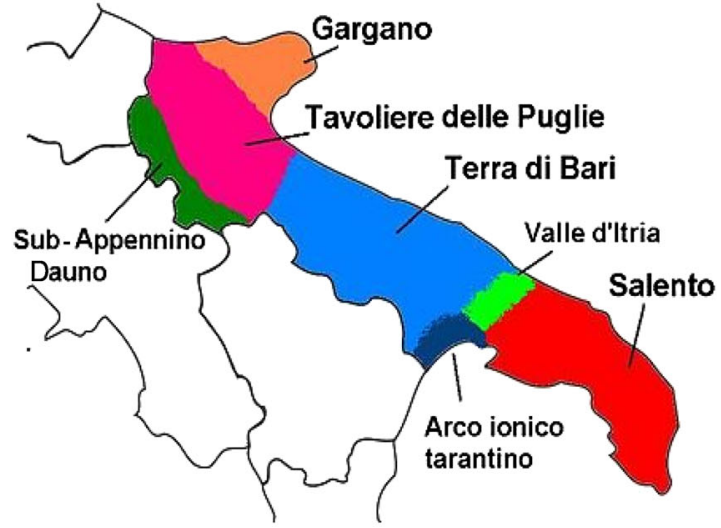

(b)

FIGURE 3 (a) Map of Puglia region (south of Italy). (b) Main areas of Puglia region [Colour figure can be viewed at wileyonlinelibrary.com]

Recent literature also refers to the works of Sharpley (2014), Almeida-García et al. (2015), and Lundberg (2017). Sharpley (2014) conducts a systematic review of resident perceptions and attitudes over a time span of almost 30 years (1984-2012). The reviews also include both qualitative and quantitative studies. Almeida-García et al. (2015) present a review on resident attitudes on economic, sociocultural, environmental, and demographic impacts including quantitative approaches. Lundberg (2017) presents an in-depth literature on resident perceptions of tourism impacts from a quantitative point of view. The paper calls for "why certain impacts are important or perceived by local residents" (Lundberg, 2017, p. 9) and "narratives, storytelling and observations" (p. 9) in future studies. In other words, the author draws the attention to a quantitative analysis of what the resident says, thinks, and knows.

\section{3 | MATERIAL AND METHODS}

The present section sheds light on the case study proposed in this work. We consider the case of the Puglia region in the south of Italy. Figure 3 shows the geolocation of the Puglia region.

The region is located in the south-east of Italy. With $1,041 \mathrm{~km}$ of coasts, the region represents about $12 \%$ of the national shoreline (ISTAT, 2014). Seventy-eight per cent of the total Puglian shoreline (700 km of coastal zone) constitutes the majority of beaches. The hinterland of the region is mostly flat and hilly and comprises seven macroareas as depicted in Figure 3b: the "Gargano"; "Sub-Appennino Dauno"; "Tavoliere delle Puglie," which is the second largest plain in Italy; "Terra di Bari" with the uplands of "Murge"; "Salento" (one of the most evocative baroque areas in Italy); "Arco ionico tarantino"; and "Valle d'Itria," which hosts one of the UNESCO heritage sites such as the Trulli. ${ }^{2}$

The Puglia region is rich in terms of landscape, natural, and cultural resources, and these contribute to the development of tourism

${ }^{2}$ Trulli are an ancient drywall limestone construction with typical conical roofs. Since 1996, the Trulli are inscripted in the UNESCO world heritage list (http://whc.unesco.org/en/list/ 787). activities within the region. The performance of tourism in 2017 saw a $4.7 \%$ increase of arrivals and a $5.2 \%$ increase of overnight stays compared with the previous year. The average stay is about four nights. The rate of internationalization also shows a $22 \%$ increase compared with the year 2016 (Agenzia Regionale del Turismo, 2018). Finally, foreign visitors spent about $€ 659$ million to visit the Puglia region in 2016 , and the spending rate increased by about $25 \%$ compared with the year 2015 (Istituto Gugliemo Tagliacarne, 2018).

\section{1 | Survey design}

This section illustrates the construction of the survey analysis and the descriptive statistics of the obtained responses. The questionnaire is divided into five sections. The first part is designed to assess sociodemographic aspects of the respondents. The second part aims to perceive the level of general information of tourism. The third and fourth parts of the questionnaire investigate resident perception on sociocultural and environmental and economic impacts of tourism, respectively. In the last part of the questionnaire, an open-ended question asks interviewees why tourists should visit the Puglia region. In particular, each respondent is asked to indicate a particular place of interest of the Puglia region that is less known or unknown to a tourist and give a reason explaining his or her suggestion. Data collection is carried out through the compilation of face-to-face interviews of residents (randomly chosen) occurred between June and October 2017 in the city centres of five (out of six) provinces of the Puglia region. The questionnaire is validated by a pretest conducted by over 25 respondents, also randomly chosen. A total sample of 312 respondents were interviewed. After dropping 85 inconsistent observations due to incomplete returned questionnaires, the final sample includes 223 observations with a response rate of about $73 \%$.

\section{2 | Inferential analysis}

For the purpose of our case study, we employ an ordered logistic regression model. Similar to logistic regression models, ordered logistic 
models are generally used to test the relationship between a categorical variable and one or more categorical or continuous predictors. An ordered logistic regression assumes an S-shaped curve. A linear transformation is applied to the dependent variable because of non-linear extreme values and an error term that is not normally distributed and not constant across data (Peng, Lee, \& Ingersoll, 2002). Ordered logistic regression models are based on the assumption of independence of irrelevant alternatives condition. This assumption states that the choice in one category is exclusive. The parameters of the ordered logit model are generally estimated through maximum likelihood estimator, where the likelihood function for discrete values is defined in terms of the probability that that particular value is realized (Myung, 2003).

\subsection{Knowledge discovery in text or TM}

Nowadays, TM is a widely used approach to retrieve latent information from unstructured data. Feldman and Sanger (2006) argue that text encoding is the core of TM approach and is characterized by a lexical analysis including language identification such as idioms, names, numbers, dates, and phrases. TM also includes an information mining phase that "provides a paradigmatic representation of the corpus: the study of its vocabulary, i.e. the language" (Bolasco, 2005, p. 9). To conduct a TM analysis, we employ one of the current most powerful open source software such as RapidMiner Studio v. 9.0. ${ }^{3}$

\section{4 | RESULTS}

\section{1 | Survey results}

Table 1 summarizes sociodemographic information of the sample. Other descriptive statistics are shown in Tables A1-A6.

The sample is characterized, on average, by respondents aged 37 years old and predominantly women (56\%). Education is an important aspect of the sample. Forty-five per cent of respondents hold a secondary school diploma, whereas $50 \%$ of them hold a higher education degree or postgraduate degree. The remaining figure (5\%) is representative of respondents with primary school education. Job type is mostly heterogeneous, although employment in the public and private sectors (36\%) and students (30\%) is representative of the sample. Gross income ranges between $€ 12,001$ and $€ 20,000$ (21\%) and $€ 20,001$ and $€ 40,000$ (47\%), respectively; only a minority of respondents (1\%) declare to earn more than $€ 100,000$ per year. In terms of regional distribution of the residency, $72 \%$ of the sample is from the capital of the region, Bari, and $21 \%$ is from Foggia (a province in the northern part of Puglia).

The second section of the survey helps us to capture information on general knowledge of tourism (Table A3). The majority of the sample generally spends a week on holidays (61\%) and believes that tourism performance in Puglia has increased between $5 \%$ and $8 \%$ in the

${ }^{3}$ http://www.rapidminer.com
TABLE 1 Descriptive statistics: Sociodemographic information

\begin{tabular}{|c|c|c|c|}
\hline Explanatory variable & Freq & $\%$ & Cumulative \\
\hline \multicolumn{4}{|l|}{ Gender } \\
\hline Male & 98 & 44 & 44 \\
\hline Female & 125 & 56 & 100 \\
\hline \multicolumn{4}{|l|}{ Province } \\
\hline BAT & 10 & 4 & 4 \\
\hline Bari & 159 & 72 & 76 \\
\hline Brindisi & 5 & 2 & 78 \\
\hline Foggia & 46 & 21 & 99 \\
\hline Taranto & 3 & 1 & 100 \\
\hline \multicolumn{4}{|l|}{ Education } \\
\hline Primary school (6-12 age) & 12 & 5 & 5 \\
\hline Secondary school (13-18 age) & 99 & 45 & 50 \\
\hline Bachelor & 90 & 40 & 90 \\
\hline Postgraduate education & 22 & 10 & 100 \\
\hline \multicolumn{4}{|l|}{ Job status } \\
\hline Housewife & 11 & 5 & 5 \\
\hline Worker/technician & 11 & 5 & 10 \\
\hline Public/private employee & 80 & 36 & 46 \\
\hline Public/private manager & 3 & 1 & 47 \\
\hline Freelance/entrepreneur & 21 & 9 & 56 \\
\hline Artisan & 5 & 3 & 58 \\
\hline Student & 67 & 30 & 88 \\
\hline Unemployed & 11 & 5 & 93 \\
\hline Retired & 4 & 2 & 95 \\
\hline Other & 10 & 5 & 100 \\
\hline \multicolumn{4}{|l|}{ Income } \\
\hline$<€ 12,000$ & 29 & 13 & 13 \\
\hline$€ 12,001-€ 20,000$ & 46 & 21 & 34 \\
\hline$€ 20,001-€ 40,000$ & 104 & 47 & 81 \\
\hline$€ 40,001-€ 75,000$ & 32 & 15 & 94 \\
\hline$€ 75,001-€ 100,000$ & 9 & 5 & 99 \\
\hline$>€ 100,000$ & 3 & 1 & 100 \\
\hline
\end{tabular}

Source: Our elaborations.

Note. $N=223$.

last 2 years (45\%). ${ }^{4}$ This section gathers information on the relevance of touristic products such as countryside (34\% fairly), seaside $(49 \%$ very relevant), traditions and religion ( $35 \%$ fairly), natural parks $(36 \%$ little relevant), food and wine (31\% very relevant), and sport and wellness (36\% little relevant). Also, respondents declare that touristic structures are of an average quality (63\%). Finally, the last part of the general knowledge on tourism captures resident awareness on the following aspects: accessibility of a touristic place $(36 \%$ neither

${ }^{4}$ According to a report on tourism performance in Puglia (Agenzia Regionale del Turismo 2016), international arrivals increased by about $9 \%$ in 2016 . Therefore, the majority of the sample does not seem to be aware of actual tourism performances within the region. 
agree nor disagree), cultural heritage (40\% agree), landscape care $(47 \%$ neither agree nor disagree), infrastructures ( $47 \%$ neither agree nor disagree), food and wine (43\% strongly agree), entertainment ( $40 \%$ neither agree nor disagree), organization of events ( $40 \%$ neither agree nor disagree), opening times of cultural and historical sites (45\% neither agree nor disagree), resident hospitality (37\% strongly agree), tourist guides ( $41 \%$ neither agree nor disagree), and kids entertainment (38\% neither agree nor disagree).

The information gathered from the third section of the survey reveals resident perception of sociocultural and environmental impacts of tourism (Table A4). Respondents are asked to declare their degree of agreement on the following statements: "I like to see tourists in my place of residence" (44\% strongly agree); "Tourists are an opportunity to share experiences" (37\% strongly agree); "Tourism favours local sustainable development" ( $37 \%$ neither agree nor disagree, see Table A1); "I am proud to see/have tourists visiting my place of residence" (48\% strongly agree); "Tourists in my place of residence increase delinquent behaviour" (46\% strongly agree); "Tourists disrupt the normal daylife of residents" (54\% strongly agree); "Tourists contribute to the crowding of public spaces" (37\% agree); "Tourists increase noise" (54\% disagree); "Tourism preserves cultural traditions" (29\% strongly agree); and "Tourism favours the preservation of natural resources" (39\% neither agree nor disagree).

Finally, the data from the last section of the survey show relevant information on resident perception of economic impacts of tourism (Table A5). Respondents are asked to declare their degree of agreement on the following statements: "The social cost of developing tourist facilities is too high" (51\% disagree); "Tourism increases the price of real estate" (50\% neither agree nor disagree); "Tourism favours infrastructures" (39\% disagree); "Tourism favours the development and/or maintenance of local public facilities" (34\% agree); "Tourism favours the increase in the price of some goods and services" (52\% neither agree nor disagree); and finally, "Tourism stimulates employment opportunities" (44\% agree).

\section{2 | Findings of the inferential analysis}

Table A6 illustrates the estimates of the inferential analysis from the most robust model. Diagnostic test at the bottom of the table suggests that the model satisfies the proportional odds assumption (LikelihoodRatio (LR) test $=82.41 ; p$ value $=.2610$ ). Results suggest that the determinants of the probability affecting the residents' perception of tourism as a driver of local sustainable development, which are statistically significant, are the following:

1. sociodemographic variables-provinces: Bari (-) and Brindisi (-); job status: retired $(-)$ and other $(+)$; and income $(+)$;

2. general information and tourism knowledge-degree of agreement on accessibility of a place (-), degree of agreement on landscape care $(-)$, degree of agreement on infrastructures (+), and degree of agreement on organization of events $(+)$;

3. sociocultural and environmental impacts of tourism-"Tourists disrupt normal daylife of residents" (-), "Tourists increase delinquent behaviour" (-), "Tourists increase noise" (+), "Tourists contribute to the crowding of public spaces" (-); and "Tourists preserve cultural traditions" (+); and

4. economic impacts of tourism-"Tourists stimulate employment opportunities" (+).

Generally, we can interpret the signs of the ordered logistic regression output but not the magnitude of the estimated coefficients. In the case of categorical predicted variables, negative signs would indicate that a higher scale of the predictive variable is more likely to affect lower categories of the dependent variable. This means that the magnitude is higher in lower categories of the dependent variable, and vice versa. To interpret the results of the magnitudes, we refer to the estimated predicted probabilities in Table 2.

Below, we present the estimated predicted probabilities for statistically significant variables of the model's output.

\subsection{1 | Sociodemographic aspects}

The estimated sign of the provinces of Bari and Brindisi is negative, and therefore, we expect higher predicted probabilities on medium/lower scales of the dependent variable. Residents in these provinces tend to be uncertain (i.e., predicted outcome $=$ neither agree nor disagree) or have a minor perception, from their local knowledge perspective, about the issue of tourism as a driver of sustainable development. Living in Bari and Brindisi increases this uncertainty by $66 \%$ and $55 \%$, respectively. As expected, these predicted values are higher than those obtained in higher categories of the dependent variable (i.e., predicted outcome $=$ agree). We argue that Bari and Brindisi are industrial provinces (Brindisi, e.g., is an industrial city with the largest electricity plant in Italy) and that there may be a limited probability in the number of tourists returning to visit an urban/industrial place. The literature recognizes that visitors of urban destinations are less likely to return to the same urban place than visitors of nonurban destinations (Ashworth \& Page, 2011). Also, residents may identify their knowledge with the sets of negative emotions and experiences (e.g., pollution) that create, in turn, the image and quality of the city (San Martín, del Mar García-de los Salmones, Herrero, \& Pérez, 2017). Therefore, residents living in urban places would be less keen to perceive tourism as a driver of local sustainable development.

Similarly, uncertainty also arises in terms of the income predictor variable. The higher the income class of respondents, the higher the probability to remain uncertain about whether tourism favours local sustainable development. There are few studies in support of this finding. Andereck et al. (2005) did not properly consider income categories in their analysis; rather, they consider income from tourism industry and income from nontourism sources. Their findings suggest that there are no differences between these income groups in terms of community impacts, and this could partially support our result. 
TABLE 2 Estimated predicted probabilities

\begin{tabular}{|c|c|c|c|c|c|c|}
\hline $\begin{array}{l}\text { Dependent variable } \operatorname{Pr}(\text { "Tourism favours } \\
\text { local sustainable development" = agree), at } \\
\text { means }\end{array}$ & Margin & $S E$ & $\begin{array}{l}\text { Dependent variable } \operatorname{Pr} \text { ("Tourism favours } \\
\text { local } \\
\text { sustainable development" = neither agree } \\
\text { nor } \\
\text { disagree), at means }\end{array}$ & Margin & $S E$ & Impact \\
\hline Province & & & Province & & & Sociodemographic \\
\hline BAT & $0.53^{* *}$ & & BAT & $0.38^{*}$ & 0.20 & \\
\hline Brindisi & 0.05 & 0.06 & Brindisi & $0.55^{* *}$ & 0.24 & \\
\hline Foggia & $0.26^{* *}$ & & Foggia & $0.63^{* * *}$ & 0.27 & \\
\hline Taranto & 0.19 & & Taranto & $0.67^{* * *}$ & 0.12 & \\
\hline Income & & & Income & & & Sociodemographic \\
\hline$€ 40,001-€ 75,000$ & $0.16^{* *}$ & 0.07 & $€ 40,001-€ 75,000$ & $0.68^{* * *}$ & 0.04 & \\
\hline$€ 40,001-€ 75,000$ & 0.00 & 0.00 & $€ 40,001-€ 75,000$ & 0.12 & 0.10 & \\
\hline$>€ 100,000$ & 0.37 & 0.40 & $>€ 100,000$ & 0.03 & 0.06 & \\
\hline Degree of agreement on accessibility of a place & & & $\begin{array}{l}\text { Degree of agreement on accessibility of a } \\
\text { place }\end{array}$ & & & Tourism knowledge \\
\hline Strongly disagree & $0.36^{*}$ & 0.21 & Strongly disagree & 0.03 & 0.03 & \\
\hline Disagree & $0.17^{* *}$ & 0.07 & Disagree & $0.67^{* * *}$ & 0.05 & \\
\hline Neither agree nor disagree & $0.28^{* * *}$ & 0.07 & Neither agree nor disagree & $0.62^{* * *}$ & 0.06 & \\
\hline Agree & $0.10^{* *}$ & 0.03 & Agree & $0.58^{* * *}$ & 0.05 & \\
\hline Agree & $0.03^{*}$ & 0.02 & Agree & $0.58^{* * *}$ & 0.06 & \\
\hline Strongly agree & 0.00 & 0.00 & Strongly agree & 0.06 & 0.10 & \\
\hline Degree of agreement on infrastructures & & & Degree of agreement on infrastructures & & & Tourism knowledge \\
\hline Strongly disagree & $0.56^{* * *}$ & 0.07 & Strongly disagree & 0.11 & 0.06 & \\
\hline Disagree & $0.63^{* * *}$ & 0.07 & Disagree & $0.07^{* *}$ & 0.02 & \\
\hline Neither agree nor disagree & $0.66^{* * *}$ & 0.06 & Neither agree nor disagree & $0.35^{* * *}$ & 0.07 & \\
\hline Agree & 0.21 & 0.13 & Agree & $0.62^{* * *}$ & 0.07 & \\
\hline Strongly agree & 0.06 & 0.12 & Strongly agree & 0.52 & 0.38 & \\
\hline Degree of agreement on organization of events & & & $\begin{array}{l}\text { Degree of agreement on organization of } \\
\text { events }\end{array}$ & & & Tourism knowledge \\
\hline Strongly disagree & 0.03 & 0.03 & Strongly disagree & 0.15 & 0.15 & \\
\hline Disagree & $0.50^{* *}$ & 0.16 & Disagree & $0.11^{* *}$ & 0.04 & \\
\hline Neither agree nor disagree & $0.67^{* * *}$ & 0.05 & Neither agree nor disagree & $0.20^{* *}$ & 0.06 & \\
\hline Agree & $0.67^{* * *}$ & 0.05 & Agree & $0.40^{* *}$ & 0.19 & \\
\hline Strongly agree & $0.68^{* * *}$ & 0.04 & Strongly agree & $0.41^{* *}$ & 0.16 & \\
\hline $\begin{array}{l}\text { Degree of agreement on tourism disrupts normal } \\
\text { daylife }\end{array}$ & & & $\begin{array}{l}\text { Degree of agreement on tourism disrupts } \\
\text { normal daylife }\end{array}$ & & & Sociocultural \\
\hline
\end{tabular}


TABLE 2 (Continued)

\begin{tabular}{|c|c|c|c|c|c|c|}
\hline $\begin{array}{l}\text { Dependent variable } \mathrm{Pr} \text { ("Tourism favours } \\
\text { local sustainable development" = agree), at } \\
\text { means }\end{array}$ & Margin & SE & $\begin{array}{l}\text { Dependent variable Pr("Tourism favours } \\
\text { local } \\
\text { sustainable development" = neither agree } \\
\text { nor } \\
\text { disagree), at means }\end{array}$ & Margin & SE & Impact \\
\hline Strongly disagree & $0.33^{* * *}$ & 0.06 & Strongly disagree & $0.49^{* * *}$ & & \\
\hline Disagree & $0.18^{* * *}$ & 0.05 & Disagree & $0.57^{* * *}$ & & \\
\hline Neither agree nor disagree & 0.03 & 0.38 & Neither agree nor disagree & $0.67^{* * *}$ & & \\
\hline Agree & 0.00 & 0.00 & Agree & 0.01 & & \\
\hline Degree of agreement on delinquent behaviour & & & $\begin{array}{l}\text { Degree of agreement on delinquent } \\
\text { behaviour }\end{array}$ & & & Sociocultural \\
\hline Strongly disagree & $0.35^{* * *}$ & 0.07 & Strongly disagree & $0.55^{* * *}$ & 0.06 & \\
\hline Disagree & $0.20^{* * *}$ & 0.05 & Disagree & $0.67^{* * *}$ & 0.05 & \\
\hline Neither agree nor disagree & 0.14 & 0.11 & Neither agree nor disagree & $0.67^{* * *}$ & 0.05 & \\
\hline Agree & 0.01 & 0.01 & Agree & 0.25 & 0.25 & \\
\hline Strongly agree & 0.00 & 0.00 & Strongly agree & 0.06 & 0.18 & \\
\hline $\begin{array}{l}\text { Degree of agreement on tourism favours the } \\
\text { crowding of public spaces }\end{array}$ & & & $\begin{array}{l}\text { Degree of agreement on tourism favours the } \\
\text { crowding of public spaces }\end{array}$ & & & Sociocultural \\
\hline Strongly disagree & $0.20^{* * *}$ & 0.05 & Strongly disagree & $0.23^{* *}$ & 0.11 & \\
\hline Disagree & $0.25^{* * *}$ & 0.06 & Disagree & $0.40^{* *}$ & 0.15 & \\
\hline Neither agree nor disagree & $0.61^{* * *}$ & 0.07 & Neither agree nor disagree & $0.57^{* *}$ & 0.24 & \\
\hline Agree & 0.02 & 0.02 & Agree & $0.64^{* * *}$ & 0.05 & \\
\hline Strongly agree & 0.05 & 0.07 & Strongly agree & $0.67^{* * *}$ & 0.05 & \\
\hline Degree of agreement on tourism favours noise & & & $\begin{array}{l}\text { Degree of agreement on tourism favours } \\
\text { noise }\end{array}$ & & & Sociocultural \\
\hline Strongly disagree & $0.57^{* * *}$ & 0.06 & Strongly disagree & $0.06^{* *}$ & 0.02 & \\
\hline Disagree & $0.60^{* * *}$ & 0.07 & Disagree & $0.33^{* * *}$ & 0.06 & \\
\hline Neither agree nor disagree & $0.63^{* * *}$ & 0.08 & Neither agree nor disagree & $0.27^{* *}$ & 0.10 & \\
\hline Agree & 0.02 & 0.04 & Agree & 0.00 & 0.00 & \\
\hline Strongly agree & 0.57 & 0.47 & Strongly agree & 0.08 & 0.25 & \\
\hline $\begin{array}{l}\text { Degree of agreement on tourism preserves } \\
\text { traditions }\end{array}$ & & & $\begin{array}{l}\text { Degree of agreement on tourism preserves } \\
\text { traditions }\end{array}$ & & & $\begin{array}{r}\text { Sociocultural and } \\
\text { environmental }\end{array}$ \\
\hline Strongly disagree & 0.00 & 0.00 & Strongly disagree & 0.00 & 0.00 & \\
\hline Disagree & $0.39^{* * *}$ & 0.10 & Disagree & 0.04 & 0.04 & \\
\hline Neither agree nor disagree & $0.50^{* *}$ & 0.21 & Neither agree nor disagree & $0.14^{* *}$ & 0.62 & \\
\hline Agree & $0.67^{* * *}$ & 0.05 & Agree & $0.19^{* * *}$ & 0.04 & \\
\hline Strongly agree & $0.68^{* * *}$ & 0.05 & Strongly agree & $0.51^{* * *}$ & 0.08 & \\
\hline $\begin{array}{l}\text { Degree of agreement on tourism stimulates } \\
\text { employment opportunities }\end{array}$ & & & $\begin{array}{l}\text { Degree of agreement on tourism stimulates } \\
\text { employment opportunities }\end{array}$ & & & Economic \\
\hline Strongly disagree & 0.01 & 0.02 & Strongly disagree & 0.30 & 0.33 & \\
\hline Disagree & $0.40^{* *}$ & 0.20 & Disagree & $0.15^{* *}$ & 0.06 & \\
\hline Neither agree nor disagree & $0.66^{* * *}$ & 0.06 & Neither agree nor disagree & $0.22^{* *}$ & 0.07 & \\
\hline Agree & $0.61^{* * *}$ & 0.06 & Agree & $0.29^{* *}$ & 0.06 & \\
\hline Strongly agree & $0.68^{* * *}$ & 0.05 & Strongly agree & $0.51^{* *}$ & 0.17 & \\
\hline
\end{tabular}

Source: Our elaborations.

***Statistically significant at $99 \% \mathrm{Cl}$ level.

${ }^{* *}$ Statistically significant at 95\% Cl level.

*Statistically significant at $90 \% \mathrm{Cl}$ level. 


\subsubsection{General information and tourism knowledge}

As for the effects of resident attitudes on the supply side of tourism (i.e., touristic products of Puglia), the tendency of residents to positively perceive infrastructures and organization of events would, in turn, encourage tourism to favour local sustainable development. This positive trend refers to an increase by $66 \%$ of the predicted outcome (= agree) when the perception of infrastructures (degree of agreement on infrastructures $=$ neither agree nor disagree) is just about right. $\mathrm{A}$ similar consideration can be drawn for the organization of events. In this case, the predicted outcome (= agree) increases by $68 \%$ when the perception of the organization of events (degree of agreement on organization of events = strongly agree) is very high. These findings are supported by recent studies in the field of tourism management (Šegota, Mihalič, \& Kuščer, 2017; Stylidis, Biran, Sit, \& Szivas, 2014).

Other touristic products such as accessibility and landscape care appear in contrast with the above view. Residents would likely to be uncertain about the accessibility of a place as a factor affecting the perception of tourism as a driver of sustainable development. Predicted probabilities for the "neither agree nor disagree" category of the dependent variable range from 58\% (when the degree of agreement on accessibility of a place $=$ agree) to $67 \%$ (when the degree of agreement on accessibility of a place = strongly agree). Due to strong ties of local residents with their cultural and landscape heritage (Amato, Martellozzo, Nolè, \& Murgante, 2017; Attanasi, Casoria, Centorrino, \& Urso, 2013; Del Vecchio \& Passiante, 2017), residents may fear that tourists alter the conservation of the landscape and shorelines in view of infrastructures to access natural places. The issue of accessibility as a drawback of tourism developments is also taken into account in recent works by Chiu, Chan, and Marafa (2016), Zhang and Chan (2016), Suntikul and Dorji (2016), and Šegota et al. (2017).

\subsubsection{Sociocultural and environmental impacts}

As for sociocultural impacts of tourism such as criminality, disruption of normal daylife, and crowding of public spaces, there appears to be a certain degree of uncertainty that these factors may affect resident attitudes on tourism. In other words, residents would be likely to discourage the vision of tourism as a driver of sustainable development (with an increase, on average, by $67 \%$ of the predicted outcome $=$ neither agree nor disagree), when these social factors are strongly perceived. Most probably, this is due to antisocial behaviours quite often related to microcriminality (Cracolici \& Uberti, 2008). Therefore, from the resident point of view, this deeply rooted knowledge about the above factors may somehow generate ambiguities about the rising of misbehaving mechanisms also in tourists.

In contrast, the uncertainty of respondents in terms of noise perception would be likely to positively affect the predicted outcome (= agree) by $63 \%$. This means that noise is not properly recognized as a disturbance factor of normal daily life in local residents. Nonetheless, this finding would be partially in accordance with the study of Chang (1997).

Overall, the positive attitude to perceive tourism as a factor to preserve traditions increases the probability of the predicted outcome (= agree) by $68 \%$. This finding is supported by the positive impacts of tourism developments in World Heritage Sites destinations. The "Trulli" area in the heart of the Puglia region is one of the World Heritage Sites. These sites, thus, can help to contribute towards the preservation of traditions by promoting cultural activities and preserving the cultural identity of residents (Gursoy, Jurowski, \& Uysal, 2002; Jaafar, Dahalan, \& Asma Mohd Rosdi, 2014; Kim, Uysal, \& Sirgy, 2013).

\subsection{4 | Socio-economic impacts}

A similar result such as an increase of the probability of the predicted outcome (= agree) by $68 \%$ is also obtained when residents strongly agree that tourism may be considered a source of employment opportunities. Previous studies including improved standards of living, increased income, and the creation of more job opportunities also support the above finding (Andereck et al., 2005; Choi \& Sirakaya, 2006; Ko \& Stewart, 2002; Tovar \& Lockwood, 2008).

\section{3 | TM results}

Tables 3-5 show main results from the TM analysis. The emerging aspect from the TM analysis is the link between the spatial dimension

TABLE 3 Spatial dimension of places to visit

\begin{tabular}{lrr} 
Spatial area & N & $\%$ \\
\hline Municipalities & 112 & 40 \\
\hline Specific sites & 76 & 27 \\
\hline Macroareas & 69 & 25 \\
\hline Generic sites & 14 & 5 \\
\hline Other/not relevant & 10 & 4 \\
\hline
\end{tabular}

Source: Our elaborations.

TABLE 4 Top 10 most recurrent words

\begin{tabular}{|lll|}
\hline Words & Occurrence & Document occurrence \\
\hline Mare (sea) & 35 & 32 \\
\hline Gargano & 20 & 18 \\
\hline Puglia & 18 & 18 \\
\hline Polignano a Mare & 18 & 17 \\
\hline Storico (historical) & 15 & 15 \\
\hline Murgia & 14 & 13 \\
\hline Bari & 13 & 13 \\
\hline Gravina & 11 & 11 \\
\hline Città pugliesi (Puglian cities) & 10 & 10 \\
\hline Grotta (cave) & 10 & 9 \\
\hline
\end{tabular}

Source: Our elaborations. 
TABLE 5 Main correlation values between pairwise words-Pearson correlation

\begin{tabular}{lll}
\hline First attribute & Second attribute & Correlation \\
\hline Cave & Poetry & 0.77 \\
\hline Centre & Historical & 0.66 \\
\hline Castel del Monte & Trani & 0.48 \\
\hline Interest & Historical & 0.44 \\
\hline Dauno & Traditions & 0.38 \\
\hline Manfredonia & Particular & 0.38 \\
\hline Interest & Territory & 0.38 \\
\hline Particular & Port & 0.35 \\
\hline Alberobello & Trani & 0.35 \\
\hline Bari & Tourists & 0.35 \\
\hline Altamura & Territory & 0.35 \\
\hline Interest & Parks & 0.35 \\
\hline Alberobello & Castel del Monte & 0.34 \\
\hline History & Tourism & 0.34 \\
\hline Alberobello & Ostuni & 0.32 \\
\hline Ostuni & Must-see & 0.32 \\
\hline
\end{tabular}

Source: Our elaborations.

of the Puglia territories (Table 3) and the local knowledge of residents. This result contributes to a further understanding of local knowledge in tourism studies according to mainstream literature (Smith, 2001).

The spatial dimension is particular relevant for the item "municipalities" that can be observed in 112 documents and obtains the highest frequency value (almost 40\%). Similarly, residents also indicate "specific sites" to be visited (76 instances) and "macroareas" such as "Salento" (in the south of Puglia) or "Gargano" (in the north of the region; 69 instances). These areas, as already explained in the previous section, are endowed with particular resources (e.g., historical, cultural, and natural) that make them unique at regional, national, and international level. Also, residents point out "generic sites" (e.g., sea and parks; 14 instances) among the reasons to visit Puglia.

Table 4 illustrates the top 10 most recurrent words from the openended question. "Mare" (seaside) is the top reason why tourists should visit Puglia; this is followed by the macroarea "Gargano" and the item "Polignano a Mare." In addition, we find the term "Storico" (historical) and the item "Murgia" (plateau). The latter hosts the Alta Murgia National Park endowed with its Mediterranean steppe, drystone buildings, and masserie (farmsteads).

Table 5 shows main correlation values (i.e., Pearson coefficients) between pairwise terms. There emerge direct and indirect relationships. Particularly, visiting a cave inspires poetry (cave-poetry 0.77 ). This result is not surprising. Generally, famous caves such as Castellana Caves (Castellana Grotte) in the hinterland of Bari, the capital of the region, are the scenario for cultural events such as

${ }^{5}$ Polignano a Mare is a shining gem of the Puglian coast, with its white walls houses and ancient churches in the old town. Polignano a Mare is also known for its high limestone cliffs hosting the international Red Bull Cliff Diving event every year. multimedia shows, film festivals, and gospel choirs (lannace \& Trematerra, 2014). Similarly, many city centres of Puglia, according to residents, should be visited because they are considered historical (centres-historical 0.66). Indirectly, the term "interest" would be related to that of "historical" (interest-historical 0.44) as well as parks (interest-parks 0.35) and territory (interest-territory 0.38). The Daunia Mountains (in the northern part of the region) is perceived as being rich in traditions (Dauno-traditions 0.38). Indirect relationships can also be found among "must-see" sites such as Castel del MonteTrani (0.48), Alberobello-Trani (0.35), Alberobello-Castel del Monte (0.34), and Alberobello-Ostuni (0.32). The surroundings of the above sites mainly refer to places where King Frederick II built his castles (i.e., the areas nearby Trani and Castel del Monte) or the Itria Valley (i.e., the area including Alberobello and Ostuni) that is characterized by the presence of "Trulli."

The TM analysis strengthens the results obtained from the inferential analysis. In addressing the reasons why tourists should visit Puglia, the spatial dimension of local knowledge appears relevant to explain tourist attractiveness. The spatial aspect arising from local knowledge between resident attitudes and tourist destinations has received little attention by the international literature.

Our early results from the data mining approach find support from some recent works. Zhou, Xu, and Kimmons (2015) examine tourists' behaviour with geotagged images and texts to capture spatial and temporal features of local knowledge on tourism destinations to close the gap between tourist needs and resident expectations. Li, Zhou, and Wang (2018) examine the spatial overlap between tourists and local residents in 10 U.S. cities. The authors investigate the semantic content of tag clouds to study specific reasons for visiting a particular place.

As a consequence, we believe that knowledge discovered from the data mining approach (together with probabilistic models) could help institutions and stakeholders (e.g., tourism managers) to get more comprehensive and accurate understanding of the regional tourism status and close the gap between resident perception and tourists needs. On the basis of this consideration, next, we present the relevance of our results for policy implications.

\section{5 | POLICY IMPLICATIONS}

The role of local knowledge in tourism studies is not extensively analysed in the literature. The main reason is that local knowledge is deeply rooted in the personal and emotional sphere of an individual and therefore, it is still difficult to quantify its effects in terms of residents' attitudes. Similarly, sustainability issues though have emerged to steer the governance of modern societies for the well-being of present and future generations still call for responsible visions to preserve our common goods. Tourism can be seen as one of those visions.

\section{1 | Contribution}

Would local knowledge and socio-economic and environmental factors play a role in favouring resident perception of tourism as a driver of sustainable development? 
Our empirical results obtained by the inferential analysis and the TM approach to respond to our research question point us positively in this direction. The inferential analysis showed the existence of positive attitudes of the local resident towards considering regional touristic products (i.e., infrastructures and organization of events) as factors affecting the perception of tourism as a driver of local sustainable development. Similar considerations can be drawn when tourism is perceived as an employment catalyst and a factor preserving cultural traditions.

The obtained results from the TM approach underpin those from the probability model. In addressing the reasons why tourists should visit Puglia, not only local knowledge is an important element contributing to the analysis but also the spatial dimension of it appears relevant to the local resident to support the touristic attractiveness of his or her place of residence. Local knowledge, which comes from personal involvements, feelings, and daily life experiences of Puglian residents, would be translated into the identification of four main dimensional levels of the regional territory that would help explaining the attractiveness of Puglia: (a) municipalities, (b) specific sites, (c) macroareas, and (d) generic sites.

Another interesting result of the TM analysis is the highlight of latent relationships arising from local knowledge. For example, visiting a cave would inspire poetry. This is the case of Castellana Caves (Castellana Grotte), one of the biggest caves in Italy, ${ }^{6}$ which is also the scenario of many cultural events. Similarly, the local resident would also advise visiting several city centres of his or her region because these are endowed with historical features. Latent relationships would also occur between visiting historical landmarks such as castles and towns. For example, the resident recognizes the relative importance of visiting a castle like Castel del Monte (which is located in the Murgia, a hilly area in the north of Bari) to that of the city of Trani (which is located on the sea, to the north of Bari). In other words, according to the local resident, tourists should not miss visiting the city of Trani if he or she is visiting Castel del Monte.

The obtained results from both quantitative approaches would pertain recent findings and discussions of the international scientific literature, as already mentioned in the previous sections, and be in line with theoretical considerations (Smith, 2001). As such, our approach to local knowledge is coherent with a neo-populist paradigm that highlights how local people identify, participate, design, and help the implementation of policy decisions (Friedmann, 1992; Howes \& Chambers, 1979). The policymaker would then need to evaluate the relevance of local knowledge through an open and extensive dialogue with the residents.

How can institutions and local stakeholders help strengthen this dialogue in the context of our work? The obtained results would suggest that not all aspects arising from local knowledge are well captured by the regional tourism industry or by regional institutions to foster tourism as a driver of sustainable development.

${ }^{6} \mathrm{http}: / / w w w . g r o t t e t u r i s t i c h e . i t /$

${ }^{7}$ http://www.puglia365.it/.

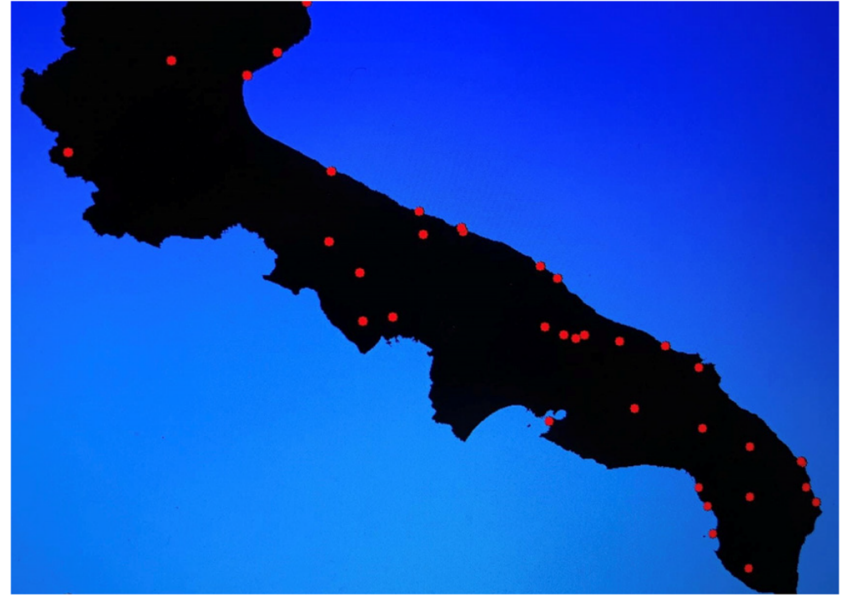

FIGURE 4 Map of local knowledge for attractiveness of tourist sites in Puglia [Colour figure can be viewed at wileyonlinelibrary.com]

To increase the potentials that the territory can offer in terms of attractiveness from both a socio-economic-environmental and local knowledge perspective, the regional institution is adopting an ad hoc policy, namely, Puglia365, ${ }^{7}$ which is a strategic plan of tourism for the years 2016-2020. It includes a participatory approach across various stakeholders to determine future guidelines on regional tourism over the next decade. The regional tourism strategy focuses on six main priority themes, these being touristic products, marketing, innovation, infrastructures, hospitality, and continuing education. To incentivize and support sustainable entrepreneurship (including sustainable tourism entrepreneurs and managers) remains cross-cutting among the above themes. Our work, although based on a pilot project, can help modern sustainable tourism entrepreneurs to meet the requirements of the touristic demand.

In addition, the insights offered by the present work can contribute to the recent tourism participatory policy initiative at regional level. How?

In our view, a participatory approach of the regional tourism policy should take into account the views of residents living in urban/industrial places, as suggested, for example, by the sociodemographic results of the predictive model. Similarly, the development of tourism curricula and their interlinkages with innovation and marketing studies should be offered by higher institutions or research centres within the region. This will help entrepreneurs and young start-ups to innovate and find alternative solutions to narrow the gap between local knowledge of the resident and the policy practitioner.

\section{6 | CONCLUSIONS}

The present work sheds light on the role of local knowledge in support of touristic attractiveness and sustainability of a place. The pilot study, carried out on one of the most visited Italian regions, has contributed to further understanding the international debate on the topic 
including both qualitative (i.e., survey analysis) and quantitative (i.e. inferential and data mining) analyses.

Main results from the inferential analysis suggest that resident attitudes towards tourism perceived as a driver of local sustainable development are moved by a positive awareness of touristic products such as infrastructures and organization of recreational events. Contrarily, a negative perception of accessibility and landscape care would not support this view.

Uncertainties of the resident attitude arise in terms of the perception of delinquent behaviour, disruption of normal daily life, and crowding of public spaces. Finally, tourism is favourably perceived as the preservation of cultural traditions and the creation of job opportunities across the region.

Results from the data mining analysis highlight the importance of the spatial dimension of the territories of Puglia, perceived by indigenous local knowledge, in explaining the touristic attractiveness of a place. In particular, our work extends mainstream literature in tourism studies and is in line with current research trends in digital and social media tourism.

Furthermore, the pilot study developed in the present work could help institutions and the modern tourism entrepreneur to recognize local knowledge as a relevant factor to uncover latent information of touristic attractiveness of a place and contribute to understanding tourism as a driver of sustainable growth patterns.

\subsection{Limitations and perspectives of further research}

The present work is not without limitations. These, however, can be seen in a positive perspective to inspire future research.

First is the sample size. Our work is based on a pilot study conducted on a small sample of 223 observations. Further research on the topic should consider a larger sample for the Puglia region (including observations from the Salento area, in the southern part of the region). Despite the above limitation, local knowledge of residents located in places of Puglia other than the Salento area emphasizes the importance of sites located in the south of Puglia for their historical traditions and beaches (red dots in Figure 4). For the specificity of local knowledge (see Section 2), other future inspirations can also include comparative cases across other Italian or Mediterranean regions.

Second is the absence of an institutional aspect. In our pilot study, no representatives of local institutions were interviewed or given surveys to complete. Future perspectives of this work may highlight the role of governmental institutions and consider the point of view of their representatives. Future works may incorporate the ongoing developments of the regional policy under consideration by current authorities.

Finally, further explorations of local knowledge can be carried out through machine learning techniques such as sentiment analysis and other predictive tools (e.g., Bayesian neural networks).

\section{CONFLICT OF INTERESTS}

None.

\section{ORCID}

Caterina De Lucia (D) https://orcid.org/0000-0001-9377-9233

Pasquale Pazienza (D) https://orcid.org/0000-0003-0318-9163

Pasquale Balena (D) https://orcid.org/0000-0002-2599-0122

Diana Caporale (ID https://orcid.org/0000-0002-5683-5264

\section{REFERENCES}

Agenzia Regionale del Turismo (2016). La Puglia nel contesto turistico mondiale. https://www.agenziapugliapromozione.it/portal/documents/10180/73227/La\%20Puglia\%20nel\%20contesto\%20turistico\% 20mondiale\%20\%282016\%29.

Agenzia Regionale del Turismo (2018). Cinque anni di turismo in Puglia. Analisi della domanda: arrivi e pernottamenti. https://www. agenziapugliapromozione.it/portal/documents/10180/2920246/ Analisi\%202013_2017.

Almeida-García, F., Balbuena-Vázquez, A., \& Cortés Macías, R. (2015). Resident's attitudes towards the impacts of tourism. Tourism Management Perspectives, 13, 33-40. https://doi.org/10.1016/j.tmp.2014.11.002

Amato, F., Martellozzo, F., Nolè, G., \& Murgante, B. (2017). Preserving cultural heritage by supporting landscape planning with quantitative predictions of soil consumption. Journal of Cultural Heritage, 23(March), 44-54. https://doi.org/10.1016/j.culher.2015.12.009

Andereck, K. L., \& Nyaupane, G. P. (2011). Exploring the nature of tourism and quality of life perceptions among residents. Journal of Travel Research, 50(3), 248-260. https://doi.org/10.1177/0047287510362918

Andereck, K. L., Valentine, K. M., Knopf, R. C., \& Vogt, C. A. (2005). Residents' perceptions of community tourism impacts. Annals of Tourism Research, 32(4), 1056-1076. https://doi.org/10.1016/j.annals.2005.03.001

Andereck, K. L., Valentine, K. M., Vogt, C. A., \& Knopf, R. C. (2007). A crosscultural analysis of tourism and quality of life perceptions. Journal of Sustainable Tourism, 15(5), 483-502. https://doi.org/10.2167/jost612.0

Ashworth, G., \& Page, S. J. (2011). Urban tourism research: Recent progress and current paradoxes. Tourism Management, 32(1), 1-15. https://doi.org/10.1016/j.tourman.2010.02.002

Attanasi, G., Casoria, F., Centorrino, S., \& Urso, G. (2013). Cultural investment, local development and instantaneous social capital: A case study of a gathering festival in the south of Italy. The Journal of SocioEconomics, 47, 228-247. https://doi.org/10.1016/j.socec.2013.05.014

Barnes, B. (2014). Interests and the growth of knowledge. London: Routledge.

Berkes, F., \& Folke, C. (2002). Back to the future: Ecosystem dynamics and local knowledge. In L. H. Gunderson, \& C. S. Holling (Eds.), Panarchy: Understanding transformations in human and natural systems (pp. 121-146). Washington, DC: Island Press.

Bolasco, S. (2005). Statistica testuale e text mining: Alcuni paradigmi applicativi. Quaderni Di Statistica, 7, 17-53.

Bond, A. J., Viegas, C. V., Coelho, C. C. D. S. R., \& Selig, P. M. (2010). Informal knowledge processes: The underpinning for sustainability outcomes in EIA? Journal of Cleaner Production, 18(1), 6-13. https:// doi.org/10.1016/j.jclepro.2009.09.002

Campolo, D., Bombino, G., \& Meduri, T. (2016). Cultural landscape and cultural routes: Infrastructure role and indigenous knowledge for a sustainable development of inland areas. Procedia - Social and Behavioural Sciences, 223, 576-682. https://doi.org/10.1016/j.sbspro.2016.05.350

Chang, T. C. (1997). Heritage as a tourism commodity: Traversing the tourist-local divide. ftp://ftp.puce.edu.ec/Facultades/ CienciasHumanas/.../turismo_desarrollo_singapore.pdf

Chiu, H. Y., Chan, C.-S., \& Marafa, L. M. (2016). Local perception and preferences in nature tourism in Hong Kong. Tourism Management Perspectives, 20, 87-97. https://doi.org/10.1016/j.tmp.2016.07.007 
Choi, H. S. C., \& Sirakaya, E. (2006). Sustainability indicators for managing community tourism. Tourism Management, 27(6), 1274-1289. https:// doi.org/10.1016/j.tourman.2005.05.018

Cracolici, M. F., \& Uberti, T. E. (2008). Geographical distribution of crime in Italian provinces: A spatial econometric analysis. Fondazione Eni Enrico Mattei, Working Paper no. 11. https://papers.ssrn.com/sol3/papers. cfm?abstract_id=1105082.

Del Vecchio, P., \& Passiante, G. (2017). Is tourism a driver for smart specialization? Evidence from Puglia, an Italian region with a tourism vocation. Journal of Destination Marketing and Management, 6(3), 163-165. https://doi.org/10.1016/j.jdmm.2016.09.005

Fazey, I., Fazey, J. A., Salisbury, J. G., Lindenmayer, D. B., \& Dovers, S. (2006). The nature and role of experiential knowledge for environmental conservation. Environmental Conservation, 33(1), 1-10. https://doi. org/10.1017/S037689290600275X

Feldman, R., \& Sanger, J. (2006). The textmining handbook: Advances approaches in analyzing unstructured data. Cambridge (UK): Cambridge University Press. DOI: 10.1017/CBO9780511546914

Frappaolo, C. (2008). Implicit knowledge. Knowledge Management Research and Practice, 6(2008), 23-25. https://doi.org/10.1057/palgrave. kmrp.8500168

Friedmann, J. (1992). Empowerment. The politics of an alternative development. Oxford: Basil Blackwell.

Gugushvili, T., Salukvadze, G., \& Salukvadze, J. (2017). Fragmented development: Tourism-driven economic changes in Kazbegi, Georgia. Annals of Agrarian Science, 15(1), 49-54. https://doi.org/10.1016/j. aasci.2017.02.005

Gursoy, D., Jurowski, C., \& Uysal, M. (2002). Resident attitudes. Annals of Tourism Research, 29(1), 79-105. https://doi.org/10.1016/S01607383(01)00028-7

Halfacree, K. H. (1995). Talking about rurality: Social representations of the rural as expressed by residents of six English parishes. Journal of Rural Studies, 11(1), 1-20. https://doi.org/10.1016/0743-0167(94)00039-C

Hansen, J., Holm, L., Frewer, L., Robinson, P., \& Sandøe, P. (2003). Beyond the knowledge deficit: Recent research into lay and expert attitudes to food risks. Appetite, 41(2), 111-121. https://doi.org/10.1016/S01956663(03)00079-5

Haven-Tang, C., \& Jones, E. (2012). Local leadership for rural tourism development: A case study of Adventa, Monmouthshire, UK. Tourism Management Perspectives, 4, 28-35. https://doi.org/10.1016/j. tmp.2012.04.006

Hiwasaki, L., Luna, E., Syamsidik, \& Shaw, R. (2014). Process for integrating local and indigenous knowledge with science for hydro-meteorological disaster risk reduction and climate change adaptation in coastal and small island communities. International Journal of Disaster Risk Reduction, 10(A), 15-27. https://doi.org/10.1016/j.ijdrr.2014.07.007

Howden, K. (2001). Indigenous traditional knowledge and native title. UNSW Law Journal, 24, 60-84.

Howes, M., \& Chambers, R. (1979). Indigenous technical knowledge: Analysis, implications, and issues. Special Review. IDS Bulletin, 10(2), 5-11.

lannace, G., \& Trematerra, A. (2014). The acoustics of the caves. Applied Acoustics, 86, 42-46. https://doi.org/10.1016/j.apacoust.2014.05.004

ISTAT (2014). Annuario Statistico Italiano 2014. https://www.istat.it/it/ files/2014/11/C01.pdf.

Istituto Gugliemo Tagliacarne (2018). http://www.tagliacarne.it/.

Jaafar, M., Dahalan, N., \& Asma Mohd Rosdi, S. (2014). Local community entrepreneurship: A case study of the Lenggong Valley. Asian Social Science, 10(10), 226-235.
Kettle, N. P., Dow, K., Tuler, S., Webler, T., Whitehead, J., \& Miller, K. M. (2014). Integrating scientific and local knowledge to inform risk-based management approaches for climate adaptation. Climate Risk Management, 4, 17-31.

Kim, K., Uysal, M., \& Sirgy, M. J. (2013). How does tourism in a community impact the quality of life of community residents? Tourism Management, 36, 527-540. https://doi.org/10.1016/j.tourman.2012.09.005

Ko, D. W., \& Stewart, W. P. (2002). A structural equation model of residents' attitudes for tourism development. Tourism Management, 23(5), 521-530. https://doi.org/10.1016/S0261-5177(02)00006-7

Kuhnert, P. M., Martin, T. G., Mengersen, K., \& Possingham, H. P. (2005). Assessing the impacts of grazing levels on bird density in woodland habitat: A Bayesian approach using expert opinion. Environmetrics, 16(7), 717-747. https://doi.org/10.1002/env.732

Kumar, S., Morstatter, F., Zafarani, R., \& Liu, H. (2013). Whom should I follow? Identifying relevant users during crises. Proceedings of the 24th ACM Conference on Hypertext and Social Media, 139-147.

Li, D., Zhou, X., \& Wang, M. (2018). Analyzing and visualizing the spatial interactions between tourists and locals: A Flickr study in ten US cities. Cities, 74(September 2017), 249-258. https://doi.org/10.1016/j. cities.2017.12.012

Lundberg, E. (2017). The importance of tourism impacts for different local resident groups: A case study of a Swedish seaside destination. Journal of Destination Marketing and Management, 6(1), 46-55. https://doi.org/ 10.1016/j.jdmm.2016.02.002

Mercer, I., Kelman, L., Taranis, S., \& Suchet-Pearson, J. (2010). Framework for integrating indigenous and scientific knowledge for disaster risk reduction. Disasters, 34(1), 214-239. https://doi.org/10.1111/j.14677717.2009.01126.x

Myung, I. J. (2003). Tutorial on maximum likelihood estimation. Journal of Mathematical Psychology, 47(1), 90-100. https://doi.org/10.1016/ S0022-2496(02)00028-7

Nonaka, I., Konno, N., \& Toyama, R. (2001). Emergence of "ba". In I. Nonaka, \& T. Nishiguchi (Eds.), Knowledge emergence: Social, technical and evolutionary dimensions of knowledge creation. Oxford: Oxford University press.

Olaide, I. A., \& Omolere, O. W. (2013). Management of indigenous knowledge as a catalyst towards improved information accessibility to local communities: A literature review. Chinese Librarianship: An International Electronic Journal, 35(2005), 87-98.

Pásková, M. (2015). The potential of indigenous knowledge for Rio Coco Geopark Geotourism. Procedia Earth and Planetary Science, 15, 886-891. https://doi.org/10.1016/j.proeps.2015.08.141

Pasquini, M., \& Alexander, M. (2005). Soil fertility management strategies on the Jos Plateau: The need for integrating 'empirical' and 'scientific' knowledge in agricultural development. The Geographical Journal, 171(2), 112-124. https://doi.org/10.1111/j.1475-4959.2005.00154.x

Peng, C.-Y. J., Lee, K. L., \& Ingersoll, G. M. (2002). An introduction to logistic regression analysis and reporting. The Journal of Educational Research, 96, 3-14. https://doi.org/10.1080/00220670209598786

Pérez Gálvez, J. C., Granda, M. J., López-Guzmán, T., \& Coronel, J. R. (2017). Local gastronomy, culture and tourism sustainable cities: The behavior of the American tourist. Sustainable Cities and Society, 32(May), 604-612. https://doi.org/10.1016/j.scs.2017.04.021

Picketts, I. M., Curry, J., \& Rapaport, E. (2012). Community adaptation to climate change: Environmental planners' knowledge and experiences in British Columbia, Canada. Journal of Environmental Planning Policy \& Planning, 14(2), 119-137. https://doi.org/10.1080/1523908X.2012.659847

Pizam, A. (1978). Tourism's impacts: The social costs to the destination community as perceived by its residents. Journal of Travel Research, 16(4), 8-12. https://doi.org/10.1177/004728757801600402 
Polanyi, M., \& Sen, A. (1966). The tacit dimension. Chicago, IL: University of Chicago.

Pollock, M. L., Legg, C. J., Holland, J. P., \& Theobald, C. M. (2007). Assessment of expert opinion: Seasonal sheep preference and plant response to grazing. Rangeland Ecology \& Management, 60(2), 125-135. https:// doi.org/10.2111/06-032R2.1

Prabhakaran, S., Nair, V., \& Ramachandran, S. (2014). Community participation in rural tourism: Towards a conceptual framework. Procedia - Social and Behavioral Sciences, 144, 290-295. https://doi.org/10.1016/j. sbspro.2014.07.298

Raymond, C. M., Fazey, I., Reed, M. S., Stringer, L. C., Robinson, G. M., \& Evely, A. C. (2010). Integrating local and scientific knowledge for environmental management. Journal of Environmental Management, 91(8), 1766-1777. https://doi.org/10.1016/j.jenvman.2010.03.023

Robertson, H. A., \& McGee, T. K. (2003). Applying local knowledge: The contribution of oral history to wetland rehabilitation at Kanyapella Basin, Australia. Journal of Environmental Management, 69(3), 275-287. https://doi.org/10.1016/S0301-4797(03)00155-5

Rothman, R. A. (1978). Residents and transients: Community reaction to seasonal visitors. Journal of Travel Research, 16(3), 8-13. https://doi. org/10.1177/004728757801600303

San Martín, H., del Mar García-de los Salmones, M., Herrero, Á., \& Pérez, A. (2017). Explaining residents' attitudes towards tourism and tourists: A new approach based on brand theory. International Journal of Tourism Research, 20(6), 738-747.

Šegota, T., Mihalič, T., \& Kuščer, K. (2017). The impact of residents informedness and involvement on their perceptions of tourism impacts: The case of Bled. Journal of Destination Marketing \& Management, 6(3), 196-206. https://doi.org/10.1016/j.jdmm.2016.03.007

Sharpley, R. (2014). Host perceptions of tourism: A review of the research. Tourism Management, 42, 37-49. https://doi.org/10.1016/j. tourman.2013.10.007

Smith, E. A. (2001). The role of tacit and explicit knowledge in the workplace. Journal of Knowledge Management, 5(4), 311-321. https://doi. org/10.1108/13673270110411733

Stylidis, D., Biran, A., Sit, J., \& Szivas, E. M. (2014). Residents' support for tourism development: The role of residents' place image and perceived tourism impacts. Tourism Management, 45, 260-274. https://doi.org/ 10.1016/j.tourman.2014.05.006

Suntikul, W., \& Dorji, U. (2016). Tourism development: The challenges of achieving sustainable livelihoods in Bhutan's remote reaches. International Journal of Tourism Research, 18(5), 447-457. https://doi.org/ 10.1002/jtr.2062

Tickner, J. A. (2015). Revisiting IR in a time of crisis: Learning from indigenous knowledge. International Feminist Journal of Politics, 17(4), 536-553. https://doi.org/10.1080/14616742.2015.1071995

Tovar, C., \& Lockwood, M. (2008). Social impacts of tourism: An Australian regional case study. International Journal of Tourism Research, 10(4), 365-378. https://doi.org/10.1002/jtr.667

Tribe, J., \& Liburd, J. J. (2016). The tourism knowledge system. Annals of Tourism Research, 57, 44-61. https://doi.org/10.1016/j.annals.2015.11.011

Van Camp, B. (2007). Keynote address. In E. K. Boon, \& L. Hens (Eds.), Indigenous knowledge systems and sustainable development: Relevance for Africa (Vol. 1). Delhi, India: Kamla-Raj Enterprises.

Van Herzele, A. (2004). Local knowledge in action-Valuing nonprofessional reasoning in the planning process. Journal of Planning Education and Research, 24(2), 197-212. https://doi.org/10.1177/0739456X04267723

Xin, S., Tribe, J., \& Chambers, D. (2013). Conceptual research in tourism. Annals of Tourism Research, 41, 66-88. https://doi.org/10.1016/j. annals.2012.12.003
Zhang, S., \& Chan, C.-S. (2016). Nature-based tourism development in Hong Kong: Importance-performance perceptions of local residents and tourists. Tourism Management Perspectives, 20, 38-46. https:// doi.org/10.1016/j.tmp.2016.07.002

Zhou, X., Xu, C., \& Kimmons, B. (2015). Detecting tourism destinations using scalable geospatial analysis based on cloud computing platform. Computers, Environment and Urban Systems, 54, 144-153. https://doi. org/10.1016/j.compenvurbsys.2015.07.006

How to cite this article: De Lucia C, Pazienza P, Balena P, Caporale D. Exploring local knowledge and socio-economic factors for touristic attractiveness and sustainability. Int J Tourism Res. 2019;1-19. https://doi.org/10.1002/jtr.2320

\section{APPENDIX A}

TABLE A1 Descriptive statistics

\begin{tabular}{lrrr}
$\begin{array}{l}\text { Dependent variable: "Tourism favours local } \\
\text { sustainable development" }\end{array}$ & Freq & $\%$ & Cumulative \\
\hline Strongly disagree & 9 & 4 & 4 \\
\hline Disagree & 51 & 23 & 27 \\
\hline Neither agree nor disagree & 82 & 37 & 64 \\
\hline Agree & 54 & 24 & 88 \\
\hline Strongly agree & 27 & 12 & 100
\end{tabular}

Source: Our elaborations.

Note. $N=223$.

TABLE A2 Descriptive statistics: Other sociodemographic variables

\begin{tabular}{lrrrc} 
Explanatory variable & Mean & SD & Min & Max \\
Age & 37 & 14 & 13 & 80 \\
No. of family components & 4 & 1 & 1 & 7 \\
No. of kids & 1 & 1 & 0 & 3 \\
\hline
\end{tabular}

Source: Our elaborations.

Note. $N=223$.

TABLE A3 Descriptive statistics: General information and tourism knowledge

Explanatory variable $\quad$ Freq \% Cumulative

Holiday time

$\begin{array}{lrrr}\text { One weekend } / 2 \text { days } & 6 & 3 & 3 \\ 3 \text { days } & 36 & 16 & 19 \\ 1 \text { week } & 135 & 61 & 80 \\ 10 \text { days } & 22 & 10 & 90 \\ >10 \text { days } & 24 & 10 & 100\end{array}$

Perception of change in tourism performance in the last 2 years 
TABLE A3 (Continued)

\begin{tabular}{|c|c|c|c|}
\hline Explanatory variable & Freq & $\%$ & Cumulative \\
\hline No change & 5 & 2 & 2 \\
\hline Decreased & 3 & 1 & 3 \\
\hline $1-4 \%$ & 38 & 17 & 20 \\
\hline $5-8 \%$ & 100 & 45 & 65 \\
\hline$>9 \%$ & 77 & 35 & 100 \\
\hline \multicolumn{4}{|c|}{ Importance of touristic product (countryside) } \\
\hline Strongly irrelevant & 23 & 10 & 10 \\
\hline Little relevant & 55 & 25 & 35 \\
\hline Fairly & 75 & 34 & 69 \\
\hline Relevant & 52 & 23 & 92 \\
\hline Very relevant & 18 & 8 & 100 \\
\hline \multicolumn{4}{|c|}{ Importance of touristic product (seaside) } \\
\hline Strongly irrelevant & 6 & 3 & 3 \\
\hline Little relevant & 11 & 5 & 8 \\
\hline Fairly & 71 & 32 & 40 \\
\hline Relevant & 24 & 11 & 51 \\
\hline Very relevant & 111 & 49 & 100 \\
\hline \multicolumn{4}{|c|}{$\begin{array}{l}\text { Importance of touristic product (traditions and } \\
\text { religion) }\end{array}$} \\
\hline Strongly irrelevant & 24 & 11 & 11 \\
\hline Little relevant & 45 & 20 & 31 \\
\hline Fairly & 76 & 35 & 65 \\
\hline Relevant & 55 & 25 & 90 \\
\hline Very relevant & 23 & 10 & 100 \\
\hline \multicolumn{4}{|c|}{ Importance of touristic product (natural parks) } \\
\hline Strongly irrelevant & 25 & 11 & 11 \\
\hline Little relevant & 81 & 36 & 47 \\
\hline Fairly & 72 & 32 & 79 \\
\hline Relevant & 36 & 16 & 95 \\
\hline Very relevant & 9 & 5 & 100 \\
\hline \multicolumn{4}{|c|}{ Importance of touristic product (food and wine) } \\
\hline Strongly irrelevant & 6 & 3 & 3 \\
\hline Little relevant & 40 & 18 & 20 \\
\hline Fairly & 64 & 29 & 49 \\
\hline Relevant & 44 & 20 & 69 \\
\hline Very relevant & 69 & 31 & 100 \\
\hline \multicolumn{4}{|c|}{$\begin{array}{l}\text { Importance of touristic product (sport and } \\
\text { wellness) }\end{array}$} \\
\hline Strongly irrelevant & 48 & 22 & 22 \\
\hline Little relevant & 81 & 36 & 58 \\
\hline Fairly & 61 & 27 & 85 \\
\hline Relevant & 26 & 12 & 97 \\
\hline Very relevant & 7 & 3 & 100 \\
\hline
\end{tabular}

TABLE A3 (Continued)

\begin{tabular}{lrrc} 
Explanatory variable & Freq & $\%$ & Cumulative \\
\hline Very bad & 5 & 2 & 2 \\
\hline Bad & 25 & 11 & 13 \\
\hline On average & 141 & 63 & 76 \\
\hline Good & 50 & 22 & 99 \\
\hline Very good & 2 & 1 & 100
\end{tabular}

Degree of agreement on accessibility of a touristic place

\begin{tabular}{lrrr} 
Strongly disagree & 15 & 7 & 7 \\
\hline Disagree & 46 & 21 & 28 \\
Neither agree nor disagree & 81 & 36 & 64 \\
\hline Agree & 67 & 30 & 94 \\
\hline Strongly agree & 14 & 6 & 100
\end{tabular}

Degree of agreement on cultural heritage

\begin{tabular}{|rrrr|} 
Strongly disagree & 10 & 4 & 4 \\
\hline Disagree & 15 & 7 & 11 \\
\hline Neither agree nor disagree & 41 & 18 & 29 \\
\hline Agree & 88 & 40 & 69 \\
\hline Strongly agree & 69 & 31 & 100
\end{tabular}

Degree of agreement on landscape care

\begin{tabular}{lrrr} 
Strongly disagree & 27 & 12 & 12 \\
\hline Disagree & 49 & 22 & 34 \\
Neither agree nor disagree & 104 & 47 & 81 \\
\hline Agree & 38 & 17 & 98 \\
\hline Strongly agree & 5 & 2 & 100
\end{tabular}

Degree of agreement on infrastructures

\begin{tabular}{lrrr} 
Strongly disagree & 29 & 13 & 13 \\
\hline Disagree & 68 & 30 & 43 \\
\hline Neither agree nor disagree & 105 & 47 & 91 \\
\hline Agree & 19 & 8 & 99 \\
\hline Strongly agree & 2 & 1 & 100
\end{tabular}

Degree of agreement on food and wine

\begin{tabular}{lrrr} 
Strongly disagree & 10 & 4 & 4 \\
\hline Disagree & 16 & 7 & 11 \\
Neither agree nor disagree & 30 & 14 & 25 \\
\hline Agree & 71 & 32 & 57 \\
Strongly agree & 96 & 43 & 100
\end{tabular}

Degree of agreement on entertainment

Strongly disagree $\quad 13 \quad 6 \quad 6$

$\begin{array}{llll}\text { Disagree } & 46 & 21 & 27\end{array}$

$\begin{array}{llll}\text { Neither agree nor disagree } & 90 & 40 & 67\end{array}$

Agree

$\begin{array}{lll}61 & 27 & 94\end{array}$

Strongly agree

$13 \quad 6 \quad 100$

Degree of agreement on organization of events

Strongly disagree

$\begin{array}{lll}15 & 7 & 7\end{array}$ 
TABLE A3 (Continued)

\begin{tabular}{|c|c|c|c|}
\hline Explanatory variable & Freq & $\%$ & Cumulative \\
\hline Disagree & 34 & 15 & 22 \\
\hline Neither agree nor disagree & 86 & 40 & 62 \\
\hline Agree & 72 & 31 & 93 \\
\hline Strongly agree & 16 & 7 & 100 \\
\hline \multicolumn{4}{|c|}{$\begin{array}{l}\text { Degree of agreement on opening times of } \\
\text { cultural and historic sites }\end{array}$} \\
\hline Strongly disagree & 22 & 10 & 10 \\
\hline Disagree & 55 & 25 & 35 \\
\hline Neither agree nor disagree & 100 & 45 & 80 \\
\hline Agree & 39 & 17 & 97 \\
\hline Strongly agree & 7 & 3 & 100 \\
\hline \multicolumn{4}{|c|}{ Degree of agreement on resident hospitality } \\
\hline Strongly disagree & 13 & 6 & 6 \\
\hline Disagree & 20 & 9 & 15 \\
\hline Neither agree nor disagree & 42 & 19 & 34 \\
\hline Agree & 65 & 29 & 63 \\
\hline Strongly agree & 83 & 37 & 100 \\
\hline \multicolumn{4}{|c|}{ Degree of agreement on tourist guides } \\
\hline Strongly disagree & 18 & 8 & 8 \\
\hline Disagree & 36 & 16 & 24 \\
\hline Neither agree nor disagree & 91 & 41 & 65 \\
\hline Agree & 55 & 25 & 90 \\
\hline Strongly agree & 23 & 10 & 100 \\
\hline \multicolumn{4}{|c|}{ Degree of agreement on kids entertainment } \\
\hline Strongly disagree & 29 & 13 & 13 \\
\hline Disagree & 46 & 21 & 34 \\
\hline Neither agree nor disagree & 84 & 38 & 72 \\
\hline Agree & 50 & 22 & 94 \\
\hline Strongly agree & 14 & 6 & 100 \\
\hline
\end{tabular}

Source: Our elaborations.

Note. $N=223$.

TABLE A4 Descriptive statistics: Sociocultural and environmental impacts of tourism

Explanatory variable

Freq \% Cumulative

"Tourists are an opportunity to share experiences"

\begin{tabular}{lrrr} 
Strongly disagree & 2 & 1 & 1 \\
\hline Disagree & 15 & 7 & 8 \\
\hline Neither agree nor disagree & 45 & 20 & 28 \\
\hline Agree & 78 & 35 & 63 \\
\hline Strongly agree & 83 & 37 & 100
\end{tabular}

"I like to see tourists in my place of residence"

Strongly disagree

100
TABLE A4 (Continued)

Explanatory variable

Freq \% Cumulative

Disagree

$\begin{array}{lll}2 & 1 & 1\end{array}$

Neither agree nor disagree

$\begin{array}{lll}49 & 22 & 23\end{array}$

Agree

$\begin{array}{lll}73 & 33 \quad 56\end{array}$

Strongly agree

$98 \quad 44 \quad 100$

"I am proud to see/have tourists visiting my place of residence"

$\begin{array}{lrrr}\text { Strongly disagree } & 1 & 0 & 0 \\ \text { Disagree } & 4 & 2 & 2 \\ \text { Neither agree nor disagree } & 32 & 14 & 16 \\ \text { Agree } & 77 & 35 & 52 \\ \text { Strongly agree } & 109 & 48 & 100\end{array}$

"Tourists in my place of residence increase delinquent behaviour/criminality"

$\begin{array}{lrrr}\text { Strongly disagree } & 1 & 0 & 0 \\ \text { Disagree } & 10 & 4 & 4 \\ \text { Neither agree nor disagree } & 12 & 5 & 9 \\ \text { Agree } & 99 & 44 & 53 \\ \text { Strongly agree } & 101 & 47 & 100\end{array}$

"Tourists disrupt the normal daylife of residents"

\begin{tabular}{lrrr} 
Strongly disagree & 2 & 1 & 1 \\
\hline Disagree & 9 & 4 & 5 \\
\hline Neither agree nor disagree & 92 & 41 & 46 \\
\hline Agree & 120 & 54 & 100 \\
\hline $\begin{array}{l}\text { "Tourists contribute to the crowding of public } \\
\text { spaces" }\end{array}$ & & \\
\hline Strongly disagree & 9 & 4 & 4 \\
\hline Disagree & 22 & 10 & 14 \\
\hline Neither agree nor disagree & 72 & 32 & 46 \\
\hline Agree & 83 & 37 & 83 \\
\hline Strongly agree & 37 & 17 & 100 \\
\hline "Tourists increase noise" & & & \\
\hline Strongly disagree & 67 & 30 & 30 \\
\hline Disagree & 121 & 54 & 84 \\
\hline Neither agree nor disagree & 30 & 13 & 97 \\
\hline Agree & 3 & 2 & 99 \\
\hline Strongly agree & 2 & 1 & 100 \\
\hline "Tourism preserves cultural traditions" & 102 & 46 & 71 \\
\hline Strongly disagree & 65 & 29 & 100 \\
\hline Disagree & & & \\
\hline Neither agree nor disagree & 2 & 1 & 1 \\
\hline Agree & 10 & 4 & 5 \\
\hline Strongly agree & 44 & 20 & 25 \\
\hline "Tourism favours the preservation of natural & & & \\
\hline & & & \\
\hline
\end{tabular}


TABLE A4 (Continued)

\begin{tabular}{lrrc} 
Explanatory variable & Freq & $\%$ & Cumulative \\
\hline Strongly disagree & 10 & 4 & 4 \\
\hline Disagree & 47 & 22 & 26 \\
\hline Neither agree nor disagree & 89 & 39 & 65 \\
Agree & 58 & 26 & 91 \\
\hline Strongly agree & 19 & 9 & 100 \\
\hline
\end{tabular}

Source: Our elaborations.

Note. $N=223$.

TABLE A5 Descriptive statistics: Economic impacts of tourism

\begin{tabular}{|c|c|c|c|}
\hline Variable & Freq & $\%$ & Cumulative \\
\hline \multicolumn{4}{|c|}{$\begin{array}{l}\text { "The social cost of developing tourist facilities is } \\
\text { too high" }\end{array}$} \\
\hline Strongly disagree & 59 & 26 & 26 \\
\hline Disagree & 114 & 51 & 77 \\
\hline Neither agree nor disagree & 39 & 18 & 95 \\
\hline Agree & 10 & 4 & 99 \\
\hline Strongly agree & 1 & 1 & 100 \\
\hline \multicolumn{4}{|c|}{ "Tourism increases the price of real estate" } \\
\hline Strongly disagree & 10 & 4 & 4 \\
\hline Disagree & 43 & 19 & 23 \\
\hline Neither agree nor disagree & 109 & 50 & 73 \\
\hline Agree & 52 & 24 & 96 \\
\hline Strongly agree & 9 & 4 & 100 \\
\hline \multicolumn{4}{|c|}{ "Tourism favours infrastructures" } \\
\hline Strongly disagree & 20 & 9 & 9 \\
\hline Disagree & 87 & 39 & 48 \\
\hline Neither agree nor disagree & 74 & 33 & 81 \\
\hline Agree & 28 & 13 & 94 \\
\hline Strongly agree & 14 & 6 & 100 \\
\hline \multicolumn{4}{|c|}{$\begin{array}{l}\text { "Tourism favours the development and/or } \\
\text { maintenance of local public facilities" }\end{array}$} \\
\hline Strongly disagree & 15 & 7 & 7 \\
\hline Disagree & 37 & 17 & 24 \\
\hline Neither agree nor disagree & 72 & 32 & 56 \\
\hline Agree & 76 & 34 & 90 \\
\hline Strongly agree & 23 & 10 & 100 \\
\hline \multicolumn{4}{|c|}{$\begin{array}{l}\text { "Tourism favours the increase in the price of } \\
\text { some goods and services" }\end{array}$} \\
\hline Strongly disagree & 8 & 4 & 4 \\
\hline Disagree & 32 & 14 & 18 \\
\hline Neither agree nor disagree & 115 & 52 & 70 \\
\hline Agree & 54 & 24 & 94 \\
\hline Strongly agree & 14 & 6 & 100 \\
\hline
\end{tabular}

TABLE A5 (Continued)

\begin{tabular}{lrrc} 
Variable & Freq & $\%$ & Cumulative \\
\hline Strongly disagree & 5 & 2 & 2 \\
\hline Disagree & 14 & 6 & 8 \\
\hline Neither agree nor disagree & 55 & 25 & 33 \\
\hline Agree & 97 & 44 & 77 \\
Strongly agree & 52 & 23 & 100 \\
\hline
\end{tabular}

Source: Our elaborations.

Note. $N=223$.

TABLE A6 Ordered logistic regression estimates

\begin{tabular}{|c|c|c|}
\hline "Tourism favours local sustainable development" & Coef. & SE \\
\hline Gender & -0.07 & 0.54 \\
\hline Age & -0.01 & 0.03 \\
\hline \multicolumn{3}{|l|}{ Province } \\
\hline Bari & $-1.57^{*}$ & 0.94 \\
\hline Brindisi & $-3.27^{* *}$ & 1.57 \\
\hline Foggia & -1.31 & 1.07 \\
\hline Taranto & -1.75 & 2.31 \\
\hline No. of family components & -0.01 & 0.17 \\
\hline \multicolumn{3}{|l|}{ Education } \\
\hline Secondary school & 0.38 & 1.01 \\
\hline Bachelor & -0.19 & 1.07 \\
\hline Postgraduate degrees & -0.26 & 1.14 \\
\hline \multicolumn{3}{|l|}{ Job status } \\
\hline Worker/technician & 0.26 & 1.57 \\
\hline Public/private employee & 1.71 & 1.24 \\
\hline Public/private manager & -3.20 & 2.22 \\
\hline Freelance/entrepreneur & 1.35 & 1.37 \\
\hline Artisan & -1.36 & 1.89 \\
\hline Student & 0.54 & 1.38 \\
\hline Unemployed & -0.58 & 1.52 \\
\hline Retired & $-3.67^{* *}$ & 1.94 \\
\hline Other & $3.10^{* *}$ & 1.55 \\
\hline \multicolumn{3}{|l|}{ Income } \\
\hline$€ 12,001-€ 20,000$ & $-1.60^{* *}$ & 0.74 \\
\hline$€ 20,001-€ 40,000$ & $-1.74^{* * *}$ & 0.71 \\
\hline$€ 40,001-€ 75,000$ & $-2.15^{* * *}$ & 0.85 \\
\hline$€ 75,001-€ 100,000$ & $-5.84^{* * *}$ & 1.24 \\
\hline$>€ 100,000$ & -2.79 & 2.09 \\
\hline \multicolumn{3}{|l|}{ Degree of agreement on accessibility of a place } \\
\hline Disagree & $-4.88^{* * *}$ & 1.13 \\
\hline Neither agree nor disagree & $-4.24^{* * *}$ & 1.16 \\
\hline Agree & $-5.53^{* * *}$ & 1.20 \\
\hline Strongly agree & $-4.87^{* * *}$ & 1.47 \\
\hline
\end{tabular}




\section{TABLE A6 (Continued)}

\begin{tabular}{|c|c|c|}
\hline "Tourism favours local sustainable development" & Coef. & SE \\
\hline \multicolumn{3}{|l|}{ Degree of agreement on cultural heritage } \\
\hline Disagree & -0.22 & 1.65 \\
\hline Neither agree nor disagree & -0.11 & 1.77 \\
\hline Agree & 0.08 & 1.73 \\
\hline Strongly agree & 0.70 & 1.74 \\
\hline \multicolumn{3}{|l|}{ Degree of agreement on landscape care } \\
\hline Disagree & -0.45 & 0.83 \\
\hline Neither agree nor disagree & -0.60 & 0.86 \\
\hline Agree & $-3.46^{* * *}$ & 1.02 \\
\hline Strongly agree & $-6.04^{* *}$ & 2.02 \\
\hline \multicolumn{3}{|l|}{ Degree of agreement on infrastructures } \\
\hline Disagree & -0.37 & 0.73 \\
\hline Neither agree nor disagree & $1.60^{* *}$ & 0.78 \\
\hline Agree & $3.28^{* *}$ & 1.19 \\
\hline Strongly agree & $4.69^{* *}$ & 2.31 \\
\hline \multicolumn{3}{|l|}{ Degree of agreement on food and wine } \\
\hline Disagree & 2.29 & 1.94 \\
\hline Neither agree nor disagree & -0.14 & 1.92 \\
\hline Agree & -0.63 & 1.94 \\
\hline Strongly agree & -1.20 & 1.92 \\
\hline \multicolumn{3}{|l|}{ Degree of agreement on entertainment } \\
\hline Disagree & 4.21 & 1.36 \\
\hline Neither agree nor disagree & 5.14 & 1.55 \\
\hline Agree & 4.60 & 1.56 \\
\hline Strongly agree & 0.48 & 1.69 \\
\hline \multicolumn{3}{|l|}{ Degree of agreement on organization of events } \\
\hline Disagree & 1.49 & 1.20 \\
\hline Neither agree nor disagree & -0.34 & 1.30 \\
\hline Agree & 0.36 & 1.34 \\
\hline Strongly agree & $4.86^{* *}$ & 1.59 \\
\hline \multicolumn{3}{|l|}{ Degree of agreement on opening times of cultural sites } \\
\hline Disagree & -1.48 & 0.95 \\
\hline Neither agree nor disagree & -1.17 & 1.07 \\
\hline Agree & -1.17 & 1.16 \\
\hline Strongly agree & -0.43 & 1.89 \\
\hline \multicolumn{3}{|l|}{ Degree of agreement on resident hospitality } \\
\hline Disagree & 1.21 & 1.38 \\
\hline Neither agree nor disagree & 0.71 & 1.54 \\
\hline Agree & 1.87 & 1.51 \\
\hline Strongly agree & 1.75 & 1.43 \\
\hline \multicolumn{3}{|l|}{ Degree of agreement on touristic guides } \\
\hline Disagree & -0.45 & 1.19 \\
\hline Neither agree nor disagree & -0.09 & 1.20 \\
\hline Agree & 0.58 & 1.28 \\
\hline
\end{tabular}

TABLE A6 (Continued)

\begin{tabular}{lll}
\hline "Tourism favours local sustainable development" & Coef. & SE \\
\hline Strongly agree & 1.19 & 1.51 \\
\hline Degree of agreement on entertainment for kids & & \\
\hline Disagree & -0.92 & 1.05 \\
\hline Neither agree nor disagree & -0.83 & 1.03 \\
\hline Agree & -0.10 & 1.14 \\
\hline Strongly agree & -0.87 & 1.36 \\
\hline Tourists disrupt normal daylife of residents & & \\
\hline Disagree & $-0.90^{*}$ & 0.48 \\
\hline Neither agree nor disagree & $-2.67^{* *}$ & 1.41 \\
\hline Agree & $-7.27^{* *}$ & 3.41 \\
\hline Tourists increase delinquent behaviour & & \\
\hline Disagree & $-0.84^{* *}$ & 0.43 \\
\hline Neither agree nor disagree & -1.27 & 1.04 \\
\hline Agree & $-3.92^{* *}$ & 1.50 \\
\hline Strongly agree & $-5.51^{*}$ & 3.00
\end{tabular}

Tourists contribute to the crowding of public spaces

Disagree

$-2.02^{* *} \quad 0.65$

Neither agree nor disagree

$-2.31^{* * *} \quad 0.72$

Agree

$-4.67^{* * *} 1.03$

Strongly agree

$-3.80^{* *} \quad 1.57$

Tourists increase noise

Disagree

$2.08^{* * *} \quad 0.54$

Neither agree nor disagree

$1.72^{* *} \quad 0.75$

Agree

$9.30^{* * *} \quad 2.08$

Strongly agree

$4.96 \quad 3.34$

Tourists increase the price of real estate

$\begin{array}{lrr}\text { Disagree } & -1.20 & 1.29 \\ \text { Neither agree nor disagree } & 0.89 & 1.28 \\ \text { Agree } & 0.41 & 1.32 \\ \text { Strongly agree } & 1.77 & 1.74 \\ \text { Tourists favour the management of public facilities } & & \\ \text { Disagree } & 0.65 & 1.11 \\ \text { Neither agree nor disagree } & 0.43 & 1.12 \\ \text { Agree } & 0.72 & 1.13 \\ \text { Strongly agree } & 1.87 & 1.27\end{array}$

Tourists favours the increase in the price of some goods

Disagree

$-0.72 \quad 1.20$

Neither agree nor disagree

$-0.24 \quad 1.09$

Agree

$1.72 \quad 1.17$

Strongly agree

$-1.55 \quad 1.42$

Tourists preserve cultural traditions

Disagree

$5.92^{* *} \quad 2.97$

Neither agree nor disagree

$7.39^{* *} \quad 2.86$

(Continues) 
TABLE A6 (Continued)

\begin{tabular}{|c|c|c|}
\hline "Tourism favours local sustainable development" & Coef. & SE \\
\hline Agree & $7.71^{* *}$ & 2.81 \\
\hline Strongly agree & $9.39^{* *}$ & 2.86 \\
\hline \multicolumn{3}{|l|}{ Tourists stimulate employment opportunities } \\
\hline Disagree & $4.37^{* *}$ & 1.96 \\
\hline Neither agree nor disagree & 2.90 & 1.78 \\
\hline Agree & $3.29^{* *}$ & 1.73 \\
\hline Strongly agree & 2.42 & 1.70 \\
\hline \multicolumn{3}{|c|}{$\begin{array}{l}\text { Number of obs }=223 \\
\operatorname{LR} \chi^{2}(103)=255.13 \\
p>\chi^{2}=.0000 \\
\text { Log likelihood }=-192.19007 \\
\chi^{2}(75)=82.41 \text { LR test of proportionality of odds across response } \\
\quad \text { categories } \\
p>\chi^{2}=.2610\end{array}$} \\
\hline
\end{tabular}

Source: Our elaborations.

${ }^{* * *}$ Statistically significant at $99 \% \mathrm{Cl}$ level.

${ }^{* *}$ Statistically significant at $95 \% \mathrm{Cl}$ level.

*Statistically significant at $90 \% \mathrm{Cl}$ level. 